\title{
Polimorfisme FokI, BsmI, ApaI, dan TaqI Gen Reseptor Vitamin D pada Kejadian Tuberkulosis Anak
}

\author{
Budi Setiabudiawan, ${ }^{1}$ Cissy B. Kartasasmita, ${ }^{1}$ Herry Garna, ${ }^{1}$ Ida Parwati, ${ }^{2}$ \\ Ani Melani Maskoen ${ }^{3}$ \\ ${ }^{1}$ Departemen Ilmu Kesehatan Anak, ${ }^{2}$ Departemen Patologi Klinik, ${ }^{3}$ Unit Penelitian Kesehatan \\ Fakultas Kedokteran Universitas Padjadjaran \\ Rumah Sakit Hasan Sadikin, Bandung
}

\begin{abstract}
Abstrak
Tuberkulosis (TB) adalah penyakit infeksi yang disebabkan oleh Mycobacterium tuberculosis. Faktor kuman saja tidak dapat menjadi faktor tunggal dalam kejadian TB. Varian polimorfisme gen reseptor vitamin D (RVD) dianggap penting hubungannya dengan kerentanan dan resistensi terhadap TB. Penelitian ini bertujuan untuk mengetahui peran polimorfisme FokI, BsmI, ApaI, dan TaqI gen RVD terhadap kejadian TB anak. Penelitian observasional analitik dengan rancangan kasus kontrol ini dilakukan di Bagian Ilmu Kesehatan Anak RSUP Dr. Hasan Sadikin Bandung dan Rumah Sakit Umum Cibabat Cimahi sejak Mei 2008-Maret 2009. Sampel terdiri dari 42 anak TB (kelompok kasus) dan 42 anak non-TB (kelompok kontrol) yang memenuhi kriteria penelitian dan diambil secara consecutive sampling. Dilakukan pemeriksaan polimorfisme FokI, BsmI, ApaI, dan TaqI gen RVD. Analisis dengan uji Chi-kuadrat, uji Mann-Whitney, menghitung rasio Odds (OR) dan 95\% CI. Kejadian polimorfisme FokI gen RVD pada kelompok kasus TB 66,7\% dan kontrol 40,5\% ( $p=0,016)$ dengan OR (95\% CI): 2,94 $(1,21-7,16)$. Kejadian polimorfisme FokI gen RVD untuk kelompok kasus TB adalah 2,94 kali lebih banyak dibandingkan dengan kontrol. Polimorfisme BsmI, ApaI, dan TaqI gen RVD tidak terdapat perbedaan bermakna antara kelompok kasus TB dibandingkan dengan kontrol ( $\mathrm{p}>0,05)$. Disimpulkan bahwa polimorfisme FokI gen RVD merupakan faktor risiko terjadinya TB anak. [MKB. 2010;42(4):187-94].
\end{abstract}

Kata kunci: Gen reseptor vitamin D, polimorfisme, tuberkulosis anak

\section{Polymorphism of FokI, BsmI, ApaI, and TaqI Vitamin D Receptor Gene on Child Tuberculosis}

\begin{abstract}
Tuberculosis (TB) is a infection disease caused by Mycobacterium tuberculosis. Mycobacterium tuberculosis itself is not the only factor of TB. Polymorphism of vitamin D receptor (VDR) gene is important on the susceptibility of TB. The aim was to find out the role of FokI, BsmI, ApaI, and TaqI VDR gene polymorphism on child TB. The observational analytic study with case control design was done in RSUP Dr. Hasan Sadikin Bandung and RSU Cibabat Cimahi, May 2008-March 2009. The subjects consisted of 42 children each for case (TB) and control (non TB) group, enrolled by consecutive sampling. The blood was analyzed for polymorphism of FokI, BsmI, ApaI, and TaqI VDR gene. Chi-square test, Mann-Whitney test, to calculate odds ratio (OR) and 95\% confidence interval (CI) were used. The incidence of FokI VDR gene polymorphism in TB case group was $66.7 \%$ and $40.5 \%$ in control group $(\mathrm{p}=0.016)$, OR $(95 \% \mathrm{CI}): 2.94$ (1.21-7.16). The FokI VDR gene polymorphism for TB group was 2.94 times greater than that for control group; while for BsmI, ApaI, and TaqI VDR gene polymorphism, there was no significant difference between TB case and control ( $\mathrm{p}>0.05)$. It is concluded, FokI VDR gene polymorphism is a risk factor of child TB. [MKB. 2010;42(4):187-94].
\end{abstract}

Key words: Child tuberculosis, polymorphism, vitamin D receptor gene 


\section{Pendahuluan}

Tuberkulosis (TB) adalah penyakit infeksi yang disebabkan oleh Mycobacterium tuberculosis (M. tuberculosis). ${ }^{1}$ Indonesia merupakan negara urutan ketiga di dunia dalam jumlah penderita TB setelah India (30\%) dan Cina (15\%) dengan persentase sebanyak $10 \%$ dari total penderita TB di dunia. ${ }^{2}$ Insidensi dan prevalensi TB pada anak bervariasi di setiap negara, diperkirakan sebanyak 3,1 juta anak di bawah 15 tahun terinfeksi $M$. tuberculosis. Berdasarkan laporan WHO sekitar 10-20\% dari seluruh kasus TB ditemukan pada anak dan sekitar $75 \%$ dari seluruh kasus TB pada anak tersebut terdapat di India, Cina, Indonesia, Pakistan, Filipina, Thailand, Bangladesh, dan Republik Demokrasi Kongo., ${ }^{3,4}$

Salah satu yang menjadi perhatian para ahli adalah mencari faktor-faktor yang menyebabkan seseorang terinfeksi $M$. tuberculosis berkembang menjadi penderita TB. Salah satunya adalah faktor genetik, karena faktor kuman saja tidak dapat menjadi faktor tunggal dalam kejadian TB. ${ }^{1,5-11}$ Meskipun satu per tiga penduduk dunia telah terinfeksi $M$. tuberculosis, hanya sekitar $10 \%$ yang akan berkembang menjadi TB. Faktor genetik merupakan salah satu faktor yang dapat menerangkan mengapa sebagian orang lebih resisten terhadap infeksi $M$. tuberculosis daripada yang lainnya. Kerentanan terhadap TB adalah poligenik, melibatkan multikandidat gen, yaitu varian dari gen major histocompatibility complex (MHC) dan non-MHC. Gen reseptor vitamin D (RVD) merupakan salah satu gen kandidat penting dari gen non-MHC yang berperan pada kejadian TB. Polimorfik varian genotipe dari gen RVD telah dianggap penting hubungannya dengan kerentanan dan resistensi terhadap TB paru. ${ }^{5,11-13}$

Vitamin D merupakan salah satu dari mediator yang dapat menghambat pertumbuhan M. tuberculosis di dalam makrofag dan monosit. Vitamin D akan memberikan efek setelah berinteraksi dengan RVD yang merupakan suatu reseptor hormon inti. RVD adalah ligandactivated transcription factor yang terdapat pada sel monosit, limfosit T, dan limfosit B., ${ }^{9,11-1,15}$

Beberapa polimorfisme gen RVD telah diindentifikasi, yaitu FokI pada ekson II, TaqI pada ekson IX, BsmI dan ApaI terletak di intron antara ekson VIII dan IX. Perubahan ekspresi mRNA RVD diperlihatkan dengan varian genotipe dari gen RVD. ${ }^{11-13}$
Genotipe tt gen RVD memperlihatkan hubungannya dengan penurunan risiko TB pada populasi Gambia. Genotipe ff dari polimorfisme FokI dan defisiensi vitamin D memperlihatkan hubungan yang erat dengan TB paru pada populasi India Gujarati yang tinggal di London. Penelitian sebelumnya memperlihatkan bahwa genotipe tt berhubungan dengan kerentanan dan genotipe TT berhubungan dengan resistensi terhadap TB paru pada wanita. Penelitian terbaru membuktikan bahwa genotipe $\mathrm{Bb}$ dan $\mathrm{FF}$ berhubungan dengan kerentanan terhadap TB pada laki-laki. ${ }^{11,12}$

Varian polimorfisme gen RVD dipengaruhi suku bangsa dan geografi. Varian polimorfisme gen RVD yang telah diindentifikasi dan berperan penting dalam hubungannya dengan kerentanan dan resistensi terhadap TB yaitu FokI, BsmI, ApaI, dan TaqI. ${ }^{13,16}$ Sampai saat ini, baik di Indonesia maupun luar negeri belum ada penelitian yang dilakukan pada anak mengenai hubungan polimorfisme FokI, BsmI, ApaI, dan TaqI gen RVD dengan TB.

Tujuan penelitian ini adalah untuk mengetahui peran polimorfisme FokI, BsmI, ApaI, dan TaqI gen RVD terhadap kejadian TB pada anak.

\section{Metode}

Bentuk penelitian ini adalah observasional analitik dengan rancangan kasus kontrol. Penelitian dilakukan di Bagian Ilmu Kesehatan Anak RSUP Dr. Hasan Sadikin Bandung dan Rumah Sakit Umum Cibabat Cimahi sejak Mei 2008 sampai dengan Maret 2009. Pemilihan sampel dilakukan secara consecutive sampling dengan besar sampel sebanyak 84 anak terdiri dari 42 anak yang menderita TB (kelompok kasus) dan 42 anak non-TB (kelompok kontrol). Kriteria inklusi kelompok kasus adalah anak berusia $\leq 14$ tahun yang menderita TB berdasarkan sistem skoring UKK Respirologi PP IDAI (skoring $\geq 6$ ) dengan uji tuberkulin positif. Kelompok kontrol adalah anak non-TB berusia $\leq 14$ tahun (skoring $<6)$ dengan uji tuberkulin negatif. Kriteria eksklusi adalah anak menderita kelainan hepar, gagal ginjal kronik, mengalami imunosupresi, dan anak yang mendapat terapi obat antituberkulosis (OAT). Kriteria drop out adalah darah mengalami lisis.

Pada kelompok kasus dan kontrol dilakukan pengambilan sampel darah sebanyak $7 \mathrm{~mL}$ ke 
dalam tabung EDTA untuk analisis DNA. Untuk mendeteksi alel FokI, BsmI, ApaI, dan TaqI dilakukan isolasi DNA dari peripheral blood mononuclear cells (PBMC) kasus TB dan kontrol dengan menggunakan metode isolation kit dari Pharmacia, kemudian 200 ng DNA digunakan sebagai templat untuk polymerase chain reaction (PCR). Analisis genotipe polimorfisme FokI, BsmI, ApaI, dan TaqI gen RVD menggunakan metode PCR restriction fragment length polymorphisms (PCR-RFLP), dengan memakai genomik DNA kasus TB dan kontrol, serta primer spesifik.

Analisis statistik yang digunakan pada penelitian ini adalah uji Chi-kuadrat, uji MannWhitney, uji t, menghitung rasio Odds (OR) dan $95 \% \mathrm{CI}$, serta analisis regresi logistik ganda.

\section{Hasil}

Berdasarkan Tabel 1, karakteristik umum baik jenis kelamin, usia maupun status gizi tidak terdapat perbedaan bermakna antara kelompok kasus TB dan kontrol (semua $p>0,05$ ) yang berarti karakteristik kedua kelompok dianggap homogen sehingga hasil pemeriksaan selanjutnya layak untuk dianalisis.

Proporsi genotipe dan alel polimorfisme gen RVD pada kelompok kasus TB dan kontrol dapat dilihat pada Tabel 2 dan Tabel 3 .

Tabel 2 menunjukkan proporsi genotipe polimorfisme gen RVD pada kelompok kasus TB dan kontrol. Pada kelompok kasus TB, proporsi genotipe terbanyak dari FokI adalah genotipe Ff sebesar 57,2\%, sedangkan pada kelompok kontrol genotipe ff sebesar 59,5\%. Proporsi genotipe terbanyak dari BsmI baik pada kelompok kasus TB maupun kontrol adalah genotipe bb, masingmasing sebesar $71,4 \%$ dan $61,9 \%$. Genotipe Aa sebesar 42,9\% merupakan proporsi genotipe terbanyak dari ApaI pada kelompok kasus TB, sedangkan pada kelompok kontrol adalah genotipe AA sebesar $54,8 \%$. Genotipe TT adalah proporsi genotipe terbanyak dari TaqI baik pada kelompok kasus TB maupun kontrol, masingmasing sebesar $97,6 \%$ dan $95,2 \%$. Secara statistik, semua genotipe baik FokI, Bsm I, ApaI, maupun TaqI tidak terdapat perbedaan bermakna antara kelompok kasus TB dan kontrol (semua $p>0,05$ ).

Pada Tabel 3 diperlihatkan proporsi alel polimorfisme gen RVD pada kelompok kasus TB dan kontrol. Pada genotipe FokI, proporsi alel terbanyak adalah alel $\mathrm{f}$, baik pada kelompok kasus TB maupun kontrol, masing-masing sebesar $61,9 \%$ dan $77,4 \%$. Proporsi alel terbanyak dari $B s m$ I baik pada kelompok kasus TB maupun kontrol adalah alel $b$, masing-masing sebesar $85,7 \%$ dan $81,0 \%$. Alel A, masing-masing sebesar $59,5 \%$ dan $72,6 \%$ merupakan proporsi alel

Tabel 1 Karakteristik Subjek pada Kelompok Kasus TB dan Kontrol

\begin{tabular}{|c|c|c|c|c|}
\hline \multirow[b]{2}{*}{ Karakteristik } & \multicolumn{2}{|c|}{ Kelompok } & \multirow{2}{*}{\multicolumn{2}{|c|}{ Kemaknaan }} \\
\hline & $\begin{array}{c}\text { Kasus TB } \\
(n=42)\end{array}$ & $\begin{array}{c}\text { Kontrol } \\
(n=42)\end{array}$ & & \\
\hline \multicolumn{5}{|l|}{ Jenis kelamin } \\
\hline Laki-laki & $23(54,8 \%)$ & $27(64,3 \%)$ & $X^{2}$ & $=0,791$ \\
\hline Perempuan & $19(45,2 \%)$ & $15(35,7 \%)$ & & $=0,374$ \\
\hline \multicolumn{5}{|l|}{ Usia (tahun) } \\
\hline$<5$ & $25(59,6 \%)$ & $21(50,0 \%)$ & $\mathrm{Z}_{\mathrm{M}-\mathrm{W}}$ & $=0,685$ \\
\hline $5-<10$ & $14(33,3 \%)$ & $14(33,3 \%)$ & $\mathrm{p}$ & $=0,494$ \\
\hline$\geq 10$ & $3(7,1 \%)$ & $7(16,7 \%)$ & & \\
\hline$\overline{\mathrm{X}}(\mathrm{SB})$ & $4,8(3,7)$ & $5,4(3,9)$ & & \\
\hline Rentang & 3,5 bln $-13,6$ th & 7,5 bln -13 th & & \\
\hline Median & 4,1 & 4,9 & & \\
\hline \multicolumn{5}{|l|}{ Status gizi } \\
\hline Malnutrisi Berat & $1 \quad(2,4 \%)$ & $(0 \%)$ & $X^{2}$ & $=1,714$ \\
\hline Malnutrisi Sedang & $7(16,7 \%)$ & $7(16,6 \%)$ & $\mathrm{p}$ & $=0,634$ \\
\hline Malnutrisi Ringan & $15(35,7 \%)$ & $12(28,6 \%)$ & & \\
\hline Normal & $19(45,2 \%)$ & $23(54,8 \%)$ & & \\
\hline
\end{tabular}

Keterangan: $\mathrm{X}^{2}=$ uji Chi-kuadrat; $\mathrm{Z}_{\mathrm{M}-\mathrm{w}}=$ uji Mann-Whitney 
Setiabudiawan B.: Polimorfisme Fokl, Bsml, Apal, dan Taql Gen Reseptor Vitamin D pada Kejadian Tuberkulosis Anak

Tabel 2 Proporsi Genotipe Polimorfisme Gen RVD pada Kelompok Kasus TB dan Kontrol

\begin{tabular}{|c|c|c|c|}
\hline \multirow[b]{2}{*}{ Frekuensi Genotipe } & \multicolumn{2}{|c|}{ Kelompok } & \multirow[b]{2}{*}{ Nilai p } \\
\hline & $\begin{array}{c}\text { Kasus TB } \\
(n=42)\end{array}$ & $\begin{array}{c}\text { Kontrol } \\
(\mathrm{n}=42)\end{array}$ & \\
\hline FokI & & & 0,054 \\
\hline $\mathrm{FF}$ & $4(9,5 \%)$ & $2(4,8 \%)$ & \\
\hline $\mathrm{Ff}$ & $24(57,2 \%)$ & $15(35,7 \%)$ & \\
\hline $\mathrm{ff}$ & $14(33,3 \%)$ & $25(59,5 \%)$ & \\
\hline BsmI & & & 0,355 \\
\hline $\mathrm{BB}$ & $0 \quad(0 \%)$ & $0 \quad(0 \%)$ & \\
\hline $\mathrm{Bb}$ & $12(28,6 \%)$ & $16(38,1 \%)$ & \\
\hline $\mathrm{bb}$ & $30(71,4 \%)$ & $26(61,9 \%)$ & \\
\hline ApaI & & & 0,239 \\
\hline AA & $16(38,1 \%)$ & $23(54,8 \%)$ & \\
\hline $\mathrm{Aa}$ & $18(42,9 \%)$ & $15(35,7 \%)$ & \\
\hline aa & $8(19,0 \%)$ & $4 \quad(9,5 \%)$ & \\
\hline TaqI & & & 1,0 \\
\hline TT & $41(97,6 \%)$ & $40(95,2 \%)$ & \\
\hline $\mathrm{Tt}$ & $1(2,4 \%)$ & $2(4,8 \%)$ & \\
\hline $\mathrm{tt}$ & $0 \quad(0 \%)$ & $0 \quad(0 \%)$ & \\
\hline
\end{tabular}

Keterangan: Nilai p dihitung berdasarkan pada uji Chi-kuadrat, kecuali genotipe Tagl dengan uji Eksak Fisher

terbanyak dari Apa I baik pada kelompok kasus TB maupun kontrol. Alel $\mathrm{T}$ adalah proporsi alel terbanyak dari TaqI baik pada kelompok kasus TB maupun kontrol, masing-masing sebesar $98,8 \%$ dan $97,6 \%$. Secara statistik dapat terlihat bahwa proporsi alel dari genotipe FokI terdapat perbedaan bermakna antara kelompok kasus TB dan kontrol $(\mathrm{p}=0,029)$ dengan OR $(95 \% \mathrm{CI}): 2,11$ $(1,02-4,37)$, sedangkan untuk genotipe Bsm , ApaI, dan TaqI tidak terdapat perbedaan bermakna antara kelompok kasus TB dan kontrol (semua $\mathrm{p}$ $>0,05)$.

Perbandingan polimorfisme FokI, BsmI, ApaI dan TaqI gen RVD antara kelompok kasus TB dan

Tabel 3 Proporsi Alel Polimorfisme Gen RVD pada Kelompok Kasus TB dan Kontrol

\begin{tabular}{|c|c|c|c|c|}
\hline \multirow[b]{2}{*}{ Frekuensi Alel } & \multicolumn{2}{|c|}{ Kelompok } & \multirow[b]{2}{*}{ Nilai $p$} & \multirow[b]{2}{*}{ OR $(95 \% \mathrm{CI})$} \\
\hline & $\begin{array}{c}\text { Kasus TB } \\
(n=84)\end{array}$ & $\begin{array}{c}\text { Kontrol } \\
(\mathrm{n}=84)\end{array}$ & & \\
\hline Genotipe FokI & & & 0,029 & \\
\hline $\mathrm{F}$ & $32(38,1 \%)$ & $19(22,6 \%)$ & & $2,11(1,02-4,37)$ \\
\hline $\mathrm{f}$ & $52(61,9 \%)$ & $65(77,4 \%)$ & & 1.0 \\
\hline Genotipe BsmI & & & 0,408 & \\
\hline B & $12(14,3 \%)$ & $16(19,0 \%)$ & & 1,0 \\
\hline $\mathrm{b}$ & $72(85,7 \%)$ & $68(81,0 \%)$ & & $1,41(0,58-3,46)$ \\
\hline Genotipe $A p a I$ & & & 0,073 & \\
\hline A & $50(59,5 \%)$ & $61(72,6 \%)$ & & 1,0 \\
\hline $\mathrm{a}$ & $34(40,5 \%)$ & $23(27,4 \%)$ & & $1,80(0,90-3,63)$ \\
\hline Genotipe $\operatorname{Taq}$ I & & & 1,0 & \\
\hline $\mathrm{T}$ & $83(98,8 \%)$ & $82(97,6 \%)$ & & 1,0 \\
\hline $\mathrm{t}$ & $1 \quad(1,2 \%)$ & $2(2,4 \%)$ & & $0,49(0,02-7,13)$ \\
\hline
\end{tabular}

Keterangan: Nilai p dihitung berdasarkan pada uji Chi-kuadrat, kecuali genotipe TaqI dengan uji Eksak Fisher 
Tabel 4 Perbandingan Polimorfisme Gen RVD antara Kelompok Kasus TB dan Kontrol

\begin{tabular}{|c|c|c|c|c|}
\hline \multirow[b]{2}{*}{ Gen RVD } & \multicolumn{2}{|c|}{ Kelompok } & \multirow[b]{2}{*}{ Nilai p } & \multirow[b]{2}{*}{ OR $(95 \% \mathrm{CI})$} \\
\hline & $\begin{array}{c}\text { Kasus TB } \\
(n=42)\end{array}$ & $\begin{array}{c}\text { Kontrol } \\
(n=42)\end{array}$ & & \\
\hline $\begin{array}{c}\text { Polimorfisme FokI } \\
\text { FF dan Ff }\end{array}$ & $28 \quad(66,7 \%)$ & $17 \quad(40,5 \%)$ & 0,016 & $2,94(1,21-7,16)$ \\
\hline $\begin{array}{c}\text { Polimorfisme } B s m \mathrm{I} \\
\text { bb dan } \mathrm{Bb}\end{array}$ & $42(100,0 \%)$ & $42(100,0 \%)$ & 1,0 & - \\
\hline $\begin{array}{l}\text { Polimorfisme ApaI } \\
\text { aa dan Aa }\end{array}$ & $26(61,9 \%)$ & $19 \quad(45,2 \%)$ & 0,126 & $1,97(0,82-4,70)$ \\
\hline $\mathrm{tt}$ dan $\mathrm{Tt}$ & $1 \quad(2,4 \%)$ & $(4,8 \%)$ & 1,0 & $0,49(0,04-5,59)$ \\
\hline
\end{tabular}

Keterangan: Nilai p dihitung berdasarkan pada uji Chi-kuadrat, kecuali genotipe TaqI dan ApaI dengan uji Eksak Fisher. OR $(95 \% \mathrm{CI})=$ odds rasio $(95 \%$ confidence interval $)$

kontrol tertera pada Tabel 4.

Tabel 4 memperlihatkan bahwa polimorfisme FokI gen RVD berbeda secara bermakna antara kelompok kasus TB dan kontrol $(\mathrm{p}=0,016)$, OR (95\% CI): $2,94(1,21-7,16)$. Polimorfisme FokI gen RVD untuk kelompok kasus TB adalah 2,94 kali lebih banyak dibandingkan dengan kontrol, sedangkan untuk polimorfisme BsmI, ApaI, dan TaqI gen RVD tidak terdapat perbedaan bermakna antara kelompok kasus TB dan kontrol $(p>0,05)$.

Pemeriksaan polimorfisme gen RVD pada penelitian ini melalui proses isolasi DNA, PCR, dilanjutkan dengan digesti oleh enzim restriksi
(PCR-restriction fragment length polymorphisms/ PCR-RFLP), dan sekuensing untuk kontrol kualitas. Gambaran elektroforesis polimorfisme FokI gen RVD hasil PCR-RFLP dapat dilihat pada Gambar 1.

Gambar 1 memperlihatkan gambaran elektroforesis hasil PCR-RFLP regio FokI. Pada Lajur 2 tampak produk PCR hasil elektoforesis sebesar 265 pasangan basa (pb). Produk PCR tersebut kemudian didigesti dengan enzim restriksi FokI. GGATG adalah regio pemotongan oleh enzim restriksi FokI. Pada lajur 3, 4, dan 7 tampak satu fragmen DNA sebesar $265 \mathrm{pb}$, berarti

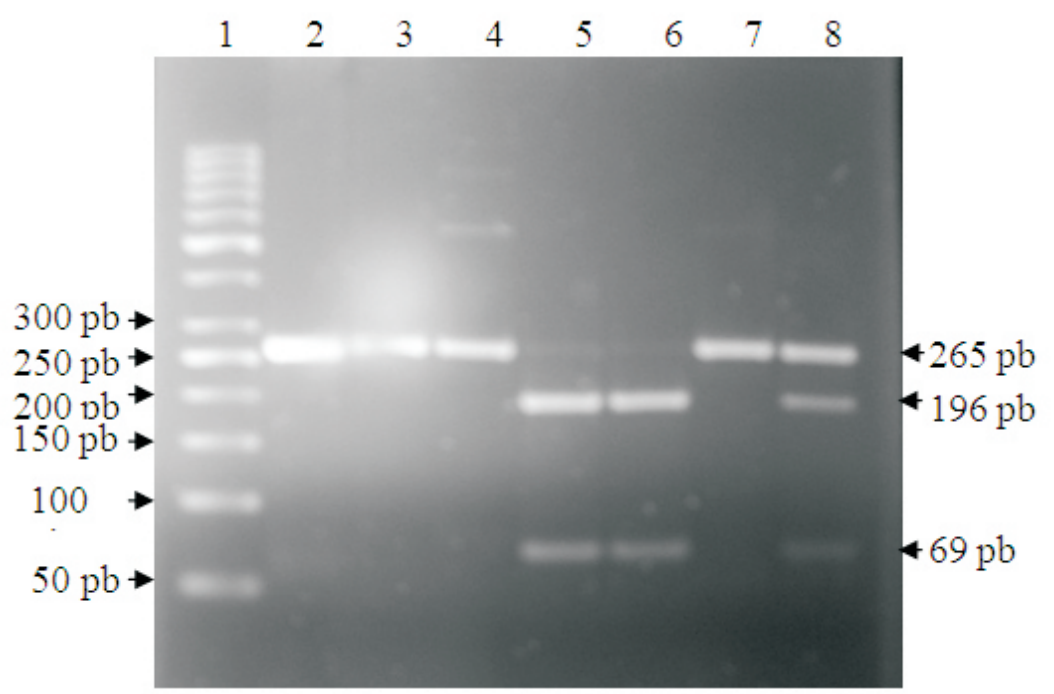

Gambar 1 Gambaran Elektroforesis Hasil PCR-RFLP Regio FokI

Keterangan:

Lajur 1 : Petanda berat molekul DNA Ladder 50

Lajur 2 : Produk PCR sebesar $265 \mathrm{pb}$

Lajur 3,4,7: Genotipe FF

Lajur 5,6 : Genotipe ff

Lajur 8 : Genotipe Ff 


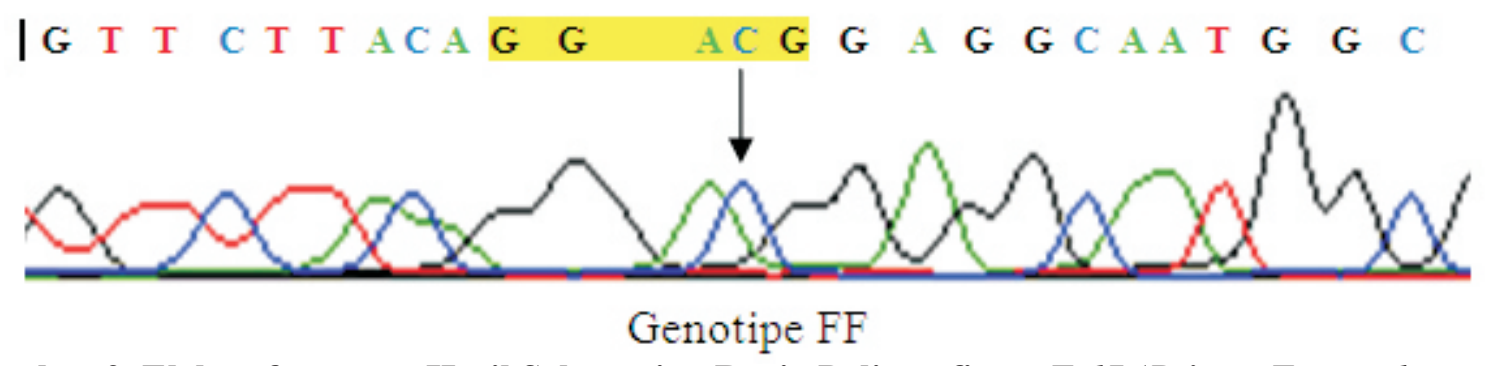

Gambar 2 Elektroforegram Hasil Sekuensing Regio Polimorfisme FokI (Primer Forward)

tidak ada regio pemotongan dari kedua alel genotipe FokI karena terdapat polimorfisme $\mathrm{T} \rightarrow \mathrm{C}$ (genotipe FF). Pada lajur 5 dan 6 terlihat dua fragmen DNA, masing-masing sebesar $69 \mathrm{pb}$ dan $196 \mathrm{pb}$, berarti terdapat regio pemotongan dari kedua alel genotipe FokI karena tidak ada polimorfisme (genotipe ff). Pada lajur 8 tampak tiga fragmen DNA, masing-masing sebesar 265 pb, $69 \mathrm{pb}$ dan $196 \mathrm{pb}$, berarti pada satu alel genotipe FokI (alel F) tidak ada regio pemotongan karena terdapat polimorfisme $\mathrm{T} \rightarrow \mathrm{C}$, sedangkan alel lainnya (alel $\mathrm{f}$ ) terdapat regio pemotongan karena tidak ada polimorfisme (genotipe $\mathrm{Ff}$ ).

Produk PCR dari beberapa sampel diperiksa juga urutan basanya dengan menggunakan alat sekuenser ABI, metode direct sequencing, oleh Laboratorium Geneka Eijkman, Jakarta, sebagai kontrol kualitas. Hasil sekuensing polimorfisme gen RVD tersebut dapat dilihat pada Gambar 2.

Pada Gambar 2 terlihat elektroforegram hasil sekuensing regio polimorfisme FokI. Basa target ditandai dengan tanda panah. Kurva yang ditunjukkan oleh tanda panah berwarna biru yang merupakan penanda basa nukleotida cytosine $(\mathrm{C})$. Puncak kurva yang terdapat pada posisi tersebut hanya satu, yang menunjukkan bahwa pada basa urutan tersebut memiliki pasangan basa $\mathrm{CC}$ sehingga genotipe polimorfisme FokI pada sampel contoh adalah FF (genotipe polimorfisme homozigot).

\section{Pembahasan}

Karakteristik umum subjek yang digunakan pada saat penelitian adalah jenis kelamin, usia, dan status gizi. Karakteristik tersebut digunakan karena ada kemungkinan besar berperan sebagai faktor risiko pada kejadian TB sehingga berpotensi menjadi variabel perancu yang dapat mempengaruhi validitas penelitian. Untuk mengurangi kerancuan yang mungkin terjadi, maka karakteristik umum subjek antara kelompok kasus TB dan kontrol harus homogen. Pada penelitian ini karakteristik umum subjek dapat dianggap homogen karena nilai $\mathrm{p}>0,05$ dari semua karakteristik seperti yang diperlihatkan pada Tabel 1, dengan demikian hasil pemeriksaan selanjutnya layak untuk diperbandingkan.

Berdasarkan pada Tabel 1, usia median kelompok kasus TB adalah 4,1 tahun, sesuai dengan kepustakaan bahwa kelompok anak usia $<5$ tahun mempunyai angka kejadian TB yang lebih tinggi dibandingkan dengan kelompok usia anak lainnya. Hal ini disebabkan faktor sistem kekebalan tubuh pada anak usia kurang dari lima tahun, terutama pada anak usia $<2$ tahun belum sempurna. Pada anak usia $<1$ tahun yang telah terinfeksi M. tuberculosis terdapat risiko untuk menderita TB sebesar $30-40 \%{ }^{4-6,8-10,17}$

Pada penelitian ini angka kejadian TB pada anak laki-laki lebih banyak dibandingkan dengan perempuan, tetapi secara statistik tidak terdapat perbedaan yang bermakna antara kelompok kasus TB dibandingkan dengan kontrol. Menurut Klein dan Iseman, ${ }^{7}$ pada masa anak tidak ada perbedaan kejadian TB antara anak laki-laki dan perempuan, tetapi setelah masa pubertas kejadian TB pada anak laki-laki dibandingkan dengan perempuan adalah 2:1.

Berdasarkan pada kepustakaan bahwa anak dengan malnutrisi berat mempunyai risiko untuk menderita TB lebih besar dibandingkan dengan status gizi lainnya. ${ }^{4-6,8-10,17}$ Pada penelitian ini kelompok kasus TB dan kontrol memiliki komposisi sebaran status gizi yang hampir sama, yaitu didominasi oleh status gizi normal, lalu malnutrisi ringan, sedang dan terakhir malnutrisi berat. Secara statistik tidak terdapat perbedaan bermakna antara kelompok kasus TB dan kontrol berdasarkan pada status gizi. Pada penelitian ini 
kelompok kasus TB yang mengalami malnutrisi berat hanya satu anak. Menurut WHO provisional guidelines for the diagnosis of pulmonary $T B$ in children, ${ }^{18}$ penurunan berat badan lebih bermakna daripada status gizi untuk mendiagnosis TB anak.

Polimorfisme merpakan variasi urutan DNA yang menimbulkan keragaman genetik dalam gene pool suatu populasi. Urutan asam amino pada protein ditentukan oleh informasi yang terdapat dalam gen yang disusun oleh DNA. Gen yang memiliki urutan-urutan yang berbeda dianggap polimorfik. Bentuk gen yang berbeda ini disebut dengan istilah alel. Polimorfisme terbentuk melalui proses mutasi yang dapat terjadi karena adanya substitusi, delesi atau insersi pada urutan polinukleotida. Polimorfisme mempunyai pengaruh yang netral pada fungsi biologis, namun dalam beberapa kondisi dapat saja menyebabkan suatu gangguan fungsi biologis. Hal ini terjadi karena terdapat perubahan susunan DNA yang mengkode protein. Polimorfisme dapat juga ditemukan pada area DNA yang tidak mengkode protein. ${ }^{19}$

Semakin berkembangnya pengetahuan mengenai biologi molekular, peran polimorfisme bermanfaat dalam mendiagnosis dan terapi suatu penyakit. Dalam populasi manusia, dijumpai perbedaan polimorfisme dalam urutan DNA yang diwariskan dalam jumlah yang besar dan hal ini berkaitan dengan suatu penyakit. ${ }^{19}$ Polimorfisme varian genotipe dari RVD telah dianggap penting hubungannya dengan kerentanan dan resistensi terhadap TB paru. Beberapa polimorfisme gen RVD telah diindentifikasi, yaitu FokI pada ekson II, TaqI pada ekson IX, BsmI dan ApaI terletak di intron antara ekson VIII dan IX..$^{11-13}$

Tabel 2 menunjukkan proporsi genotipe polimorfisme gen RVD pada kelompok kasus TB dan kontrol. Secara statistik, semua genotipe baik FokI, BsmI, ApaI, maupun TaqI tidak terdapat perbedaan bermakna antara kelompok kasus TB dibandingkan dengan kelompok kontrol ( $\mathrm{p}$ $>0,05$ ). Pada kelompok kasus TB anak, proporsi genotipe terbanyak dari FokI adalah genotipe Ff sebesar 57,2\%, BsmI genotipe bb sebesar 71,4\%, ApaI genotipe Aa sebesar 42,9\%, dan TaqI genotipe TT sebesar 97,6\%. Penelitian pada dewasa yang dilakukan oleh Zmuda dkk. ${ }^{16}$ didapatkan bahwa frekuensi genotipe ff adalah 4\% pada orang Amerika Afrika serta 13-18\% pada orang Asia dan Kaukasia. Genotipe bb BsmI adalah $2 \%$ pada orang Asia, 5\% pada orang
Amerika Afrika, dan 17\% pada orang Kaukasia. Frekuensi genotipe AA ApaI adalah 9\% pada orang Asia, 28\% orang Kaukasia, dan 44\% pada orang Amerika Afrika, sedangkan frekuensi genotipe TaqI pada populasi ini sama dengan frekuensi genotipe BsmI. Hal ini menunjukkan bahwa varian genotipe polimorfisme gen RVD dipengaruhi oleh suku bangsa dan geografi. ${ }^{16}$

Tabel 4 menunjukkan adanya perbedaan yang bermakna polimorfisme FokI gen RVD antara kelompok kasus TB dibandingkan dengan kelompok kontrol, sedangkan untuk polimorfisme BsmI, ApaI, dan TaqI gen RVD tidak terdapat perbedaan bermakna. Kejadian polimorfisme FokI gen RVD pada kelompok kasus TB adalah $66,7 \%$ dan 2,94 kali lebih banyak dibandingkan dengan kontrol.

Single nucleotide polymorphism (SNP) merupakan variasi urutan DNA yang terjadi ketika satu nukleotida dalam genom berbeda antara individu berbeda dalam satu spesies. SNP dapat terjadi pada area pengkode gen, area non-coding gen, atau pada area antar gen. SNP pada area pengkode dikelompokkan menjadi 2 tipe, yaitu nonsynonymous dan synonymous polymorphism. Pada nonsynonymous polymorphism terjadi perubahan asam amino pada susunan polipeptida, perubahan tersebut dapat bersifat missense, yaitu perubahan yang menghasilkan asam amino berbeda. Polimorfisme FokI gen RVD terjadi pada ekson, area DNA yang mengkode protein, sehingga terjadi perubahan pada susunan DNA dan perubahan tersebut menghasilkan asam amino berbeda. Pada synonymous polymorphism tidak terjadi perubahan asam amino. Tipe polimorfisme ini disebut dengan istilah silent mutation. ${ }^{20}$ Polimorfisme BsmI dan ApaI gen RVD terletak di intron, area DNA yang tidak mengkode protein, polimorfisme ini dianggap netral karena tidak mempengaruhi suatu fungsi protein, akan tetapi mempengaruhi proses splicing atau kendali transkripsi. Polimorfisme TaqI gen RVD terjadi pada ekson akan tetapi tidak mengubah hasil akhir urutan asam amino (silent mutation). ${ }^{11-13}$

Pada polimorfisme FokI gen RVD terdapat polimorfisme transisi TC pada kodon ATG pertama dari dua daerah inisiasi yang potensial di ekson II, sehingga akan menyebabkan perubahan ATGACG dan perubahan ini ditentukan dengan menggunakan enzim restriksi FokI endonuklease. GGATG adalah regio pemotongan oleh enzim restriksi FokI. Individu dengan alel C (disebut 
dengan F) menginisiasi translasi pada kodon ATG kedua karena kodon ATG pertama telah menjadi ACG sehingga tidak lagi berfungsi sebagai kodon start dan akan menyebabkan kehilangan tiga asam amino dibandingkan dengan protein RVD dengan ukuran lengkapnya (full-length). Sebaliknya individu dengan alel $T$ (disebut dengan $\mathrm{f}$ ) menginisiasi translasi pada kodon ATG pertama dan mensintesis protein RVD full-length (427 asam amino). Alel $\mathrm{f}$ adalah common allel (wild type), terdapat regio pemotongan sehingga menghasilkan fragmen DNA sebesar $69 \mathrm{pb}$ dan $196 \mathrm{pb}$. Alel F adalah infrequent allele (alel mutan), tidak terdapat regio pemotongan karena adanya polimorfisme $(\mathrm{T} \rightarrow \mathrm{C})$ sehingga terlihat fragmen DNA sebesar 265 pb. ${ }^{11,12,16}$

Pada penelitian orang dewasa didapatkan bahwa genotipe tt dari polimorfisme TaqI gen RVD berhubungan dengan penurunan risiko TB pada populasi Gambia. ${ }^{16}$ Berdasarkan pada penelitian yang dilakukan oleh Selvaraj dkk. ${ }^{12}$ didapatkan bahwa genotipe ff dari polimorfisme FokI gen RVD dan defisiensi vitamin D memperlihatkan hubungan yang erat dengan TB paru dewasa pada populasi India Gujarati yang tinggal di London.

Simpulan penelitian ini adalah polimorfisme FokI gen merupakan faktor risiko terjadinya TB pada anak.

\section{Daftar Pustaka}

1. Frieden TR, Sterling TR, Munsiff SS, Watt CJ, Dye C. Tuberculosis. Lancet. 2003;362:887-99.

2. WHO. Tuberkulosis di Indonesia. Geneva: World Health Organization; 1991.

3. Morcillo N. Tuberculosis in children. Dalam: Palmino JC, Leao SC, Ritacco V, penyunting. Tuberculosis 2007 from basic science to patient care. Edisi ke-1. Brazil: an Urestricted Educational Grant; 2007. hlm. 525-6.

4. Marais BJ, Gie RP, Schaaf, Beyers N, Donald PR, Starke JR. Childhood pulmonary tuberculosis. Am J Respir Crit Care Med. 2006;173:1078-90.

5. Marais BJ. Tuberculosis in children. Pediatr Pulmonol. 2008;43:322-9.

6. Mandalakas AM, Starke JR. Tuberculosis and nontuberculosis mycobacterial disease. Dalam: Chernick V, Boat TF, Wilmott RW, Bush A, penyunting. Kendig's disorders of the respiratory tract in children. Edisi ke-7. Philadelphia: Saunders Elsevier; 2006. hlm. 507-29.

7. Klein M, Iseman MD. Mycobacterial infections.
Dalam: Taussig LM, Landau LI, penyunting. Pediatric respiratory medicine. Edisi ke-1. St. Louis: Mosby; 1999. hlm. 702-32.

8. Young J, O'Connor ME. Risk factors associated with latent tuberculosis infection in Mexican American children. Pediatrics. 2005;115:e647-53.

9. Spence DPS, Hotchkiss J, Williams CSD, Davies PDO. Tuberculosis and poverty. BMJ. 1993;307: 759-61.

10. Tocque K, Bellis MA, Beeching NJ, Davies PDO. A case-control study of lifestyle risk factors associated with tuberculosis in Liverpool, NorthWest England. Eur Respir J. 2001;18:959-64.

11. Selvaraj P, Candra G, Jawahar MS, Rani MV, Rajeshwari DN, Narayanan PR. Regulatory role of vitamin D reseptor gen variants of BsmI, ApaI, TaqI, and FokI polymorphisms on macrophage phagocytosis and lymphoproliferative response to Mycobacterium tuberculosis antigen in pulmonary tuberculosis. J Clin Immunol. 2004;24:523-32.

12. Selvaraj P, Chandra G, Kurian SM, Reetha AM, Narayanan PR. Association of vitamin D receptor gene variants of BsmI, ApaI and FokI polymorphisms with susceptibility or resistance to pulmonary tuberculosis. Curr Sci. 2003;84:15648.

13. Lewis SJ, Baker I, Smith GD. Meta-analysis of vitamin D receptor polymorphisms and pulmonary tuberculosis risk. Int J Tuberc Lung Dis. 2005; 9(10):1174-7.

14. Endres BB, Rude RK. Mineral and bone metabolism. Dalam: Burtis CA, Ashwood ER, Bruns DE, penyunting. Tietz textbook of clinical chemistry and molecular diagnostic. Edisi ke-4. St Louis Missouri: Elsevier Saundres; 2006. hlm. 1891-965.

15. Omerod LP, Charlett A, Gilham C, Darbyshire JH, Watson JM. Geographical distribution of tuberculosis notification in national surveys of England and Wales in 1988 and 1993: report of the public health laboratory service/British Thoracic Society/Department of Health Collaborative Group. Thorax. 1998;53:176-81.

16. Zmuda JM, Cauley JA, Ferrel RE. Molecular epidemiologi of vitamin $\mathrm{D}$ receptor gene variants. Epidemiol Rev. 2000;22:203-11.

17. Vallejo JG, Ong LT, Starke JR. Cilical features, diagnosis, and treatment of tuberculosis in infants. Pediatrics. 1994;94:1-7.

18. World Health Organization. WHO tuberculosis programme framework for effective tuberculosis control. WHO/TB/94. Geneva: WHO; 1994.

19. Hardy-Weinberg principle (diuduh: Oktober 2009). Tersedia dari: http://en.wikipedia.org/wiki/ Hardy\%E2\%80\%93Weinberg.

20. Pearson H. Silent mutations speak up. Nature. 2006;DOI 10.1038. 